\title{
IL-17F promotes osteoblastic osteogenesis via the MAPK/ERK1/2 signaling pathway
}

\author{
NA ZHANG ${ }^{1}$, MIN CUI $^{1}$, XUDONG LIU ${ }^{2}$, LINGZHI YU $^{1}$, \\ $\mathrm{XU} \mathrm{ZHAO}^{3}$, LUNING CAO ${ }^{4}$ and YUANYUAN JI ${ }^{5}$ \\ ${ }^{1}$ Department of Pain Medicine, Jinan Central Hospital, Cheeloo College of Medicine, Shandong University, \\ Jinan, Shandong 250013; ${ }^{2}$ Department of Pain Medicine, Shandong University Qilu Hospital, Jinan, Shandong 250012; \\ ${ }^{3}$ Department of Anesthesiology, Shandong Provincial Hospital, Jinan, Shandong 250021; \\ ${ }^{4}$ Department of Pain Medicine, Affiliated Hospital of Jining Medical University, Jining, Shandong 272001; \\ ${ }^{5}$ Department of Anesthesiology, Affiliated Hospital of Qingdao University, Qingdao, Shandong 266000, P.R. China
}

Received April 9, 2020; Accepted July 23, 2020

DOI: $10.3892 / \mathrm{etm} .2021 .10486$

\begin{abstract}
Osteoimmunology is a field that focuses on the interactions between the skeletal and immune systems, and has become a focus of research over the years. The role of interleukin (IL)-17F, a proinflammatory cytokine, in bone regeneration and its signal transduction are not completely understood. The aim of the present study was to evaluate the function of IL-17F and the possible mechanisms underlying IL-17F in osteoblasts in vitro. Osteoblasts derived from newborn rats were treated with various concentrations of IL-17F. The pro-osteogenic effects of IL-17F were assessed at the cellular and molecular level. The results demonstrated that IL-17F promoted osteoblast proliferation, differentiation and mineralization. Reverse transcription-quantitative PCR and western blotting indicated that IL-17F treatment upregulated osteogenesis-related factors, including bone morphogenetic protein-2, Runt-related transcription factor-2 (Runx2) and Osterix, and downregulated Noggin compared with the control group. Subsequently, whether the IL-17F receptors, IL-17 receptor (IL-17R) A and IL-17RC, served a role in the effects of IL-17F on osteoblasts was investigated. The mRNA expression levels of IL-17RA and IL-17RC were upregulated in IL-17F-treated osteoblasts compared with control osteoblasts. Furthermore, U0126, a MAPK/ERK1/2 inhibitor, was utilized to investigate the mechanisms underlying IL-17F. The results indicated that compared with the control group, IL-17F increased the protein expression of phosphorylated-ERK1/2,
\end{abstract}

Correspondence to: Professor Lingzhi Yu, Department of Pain Medicine, Jinan Central Hospital, Cheeloo College of Medicine, Shandong University, 105 Jiefang Road, Jinan, Shandong 250013, P.R. China

E-mail: pain-relief@163.com

Keywords: interleukin-17F, osteoblast, osteogenesis, interleukin-17F receptor, MAPK, ERK1/2
Runx 2 and Osterix, whereas U0126 reversed IL-17F-mediated effects. Collectively, the results of the present study suggested that IL-17F promoted osteoblastic osteogenesis via the MAPK/ERK1/2-mediated signaling pathway. IL-17F promoted osteogenesis, including proliferation, differentiation and mineralization activity, indicating that IL-17F may serve as a potential therapeutic target for osteoblast-mediated bone loss disease.

\section{Introduction}

Osteoimmunology, a field that focuses on the interaction between the skeletal and immune systems, proposes that an imbalance between pro- and anti-inflammatory cytokines may serve as the mechanism underlying osteogenesis (1). A wide repertoire of cytokines secreted by $\mathrm{T}$ cells, some pre-osteogenic and some antiosteogenic, are closely associated with bone metabolism (1). Interleukin (IL)-17 is a family of cytokines released by $\mathrm{CD}^{+} \mathrm{T}$ cells (2). Numerous studies have demonstrated the role of IL-17 in bone diseases, including spondyloarthropathies, rheumatoid arthritis and ankylosing spondylitis (3-5). IL-17 has also been reported to promote osteoblast differentiation, bone regeneration and remodeling in mice (6). The IL-17 family comprises six members, from IL-17A to IL-17F. IL-17A and IL-17F are dominant proinflammatory cytokines, exhibiting the highest degree of sequence homology $(7,8)$. IL-17A enhances bone regeneration and induces the osteogenic differentiation of human mesenchymal stem cells $(9,10)$. IL-17F family members have been identified as important regulators of bone regeneration during the early phase of fracture repair (11). IL-17F treatment promotes MC3T3-E1 cell differentiation and maturation $(12,13)$, and increases the expression of osteoblast bone markers (11). Therefore, the aforementioned studies suggested a novel association between T-cells and osteoblast biology, highlighting IL-17F as a key element. In the present study, osteoblasts derived from newborn rats were employed to examine the potential role of IL-17F in osteoblastic osteogenesis, including proliferation, differentiation and mineralization activity in vitro. 
The activation of bone morphogenetic protein-2 (BMP-2) signaling is a critical regulator of osteogenesis (14). BMP-2 is one of the most potent cytokines that promotes mesenchymal cell differentiation into osteoblasts in vitro and induces bone formation in vivo $(15,16)$. Noggin, an extracellular BMP antagonist, limits BMP-2 action and is induced by BMP-2 (17). The imbalance between BMP-2 and Noggin can cause abnormal bone metabolism (18). Runt-related transcription factor-2 (Runx2) and Osterix, essential transcription factors for osteogenesis, are BMP-2-regulated targets (19). It was hypothesized that IL-17F influences the aforementioned factors, thus affecting osteogenesis. Therefore, in the present study, the expression levels of BMP-2, Runx2, Osterix and Noggin were detected following IL-17F treatment.

IL-17 receptor (IL-17R) is expressed in almost every cell type, acting on diverse tissues throughout the body (20). IL-17R consists of five subunits, from IL-17RA to IL-17RE $(21,22)$. IL-17A and IL-17F exist as homodimers or heterodimers to bind IL-17RA and IL-17RC receptor complexes, activating downstream IL-17 receptor intracellular signaling (20). IL-17F signal transduction has been observed in non-osteoblasts, such as immune cells, epithelial cell, astrocytes and fibroblasts $(20,23)$. The ligand-receptor interaction mediates tumor necrosis factor receptor-associated factor 6 ubiquitination, resulting in the phosphorylation of downstream kinases, including ERK1/2, which is a member of the MAPK family, ultimately inducing IL-17F target gene expression (24). MAPK/ERK1/2 serves a crucial role in numerous cellular responses, including cell proliferation, differentiation and survival $(25,26)$. The present study aimed to determine whether IL-17F affected osteoblast osteogenesis via the MAPK/ERK1/2 signaling pathway and to determine which type of IL-17R was involved in the process.

\section{Materials and methods}

Osteoblast isolation, culture and identification. All animal experimental protocols were approved by the Medical Ethics Committee of Jinan Central Hospital Affiliated to Shandong University, Shandong, China (approval no. GG2016-006-02). Calvarias were obtained from 8 Wistar rats (age, $<24 \mathrm{~h}$; weight, 5-8 g; 4 male and 4 female) procured from the Laboratory Animal Center of Shandong University, Shandong, China following sacrifice by cervical dislocation. Osteoblasts were isolated using trypsin (Jinan Fowler Biotechnology Co., Ltd.), type II collagenase (Suzhou BioTOP Technical Service Co., Ltd.) and the improved tissue-culture method (27). Osteoblasts were incubated in $5 \% \mathrm{CO}_{2}$ at $37^{\circ} \mathrm{C}$ with $100 \%$ relative humidity. Osteoblasts were purified by the differential adhesion method (28). Cell morphology and proliferation were assessed using an inverted phase contrast microscope. Osteoblasts were identified by alkaline phosphatase (ALP) staining using a cALP stain kit (Nanjing Jiancheng Bioengineering Institute), according to the manufacturer's protocol. Briefly, cells were fixed for $3 \mathrm{~min}$ at $25^{\circ} \mathrm{C}$ and rinsed with distilled water. Following this, matrix liquid (provided in the cALP stain kit) was added and cells were kept in the dark at $37^{\circ} \mathrm{C}$ for $15 \mathrm{~min}$. Cells were then stained with staining reagent for 5 min at $25^{\circ} \mathrm{C}$, rinsed with distilled water for $30 \mathrm{sec}$ at $25^{\circ} \mathrm{C}$, re-stained $30 \mathrm{sec}$ at $25^{\circ} \mathrm{C}$ and rinsed with distilled water for $30 \mathrm{sec}$ at $25^{\circ} \mathrm{C}$, in accordance with kit instructions. Images were captured at a magnification of $\mathrm{x} 200$ under a light microscope. After staining, 100 osteoblasts and all ALP-positive-osteoblasts was counted. The ALP-positive rate was then calculated by assessing ALP-positive-osteoblasts/100 osteoblasts. Purified osteoblasts (4th generation) were used for subsequent experiments.

Prior to IL-17F treatment, osteoblasts were seeded into a 96-well plate at $4 \times 10^{4} /$ well for the MTT analysis and ALP activity assay, or into a 6 -well plate at $2 \times 10^{5} /$ well for RT-qPCR and western blotting at $37^{\circ} \mathrm{C}$ for $24 \mathrm{~h}$. Subsequently, cells were serum starved at $37^{\circ} \mathrm{C}$ for $24 \mathrm{~h}$ in serum-free DMEM (Jinan Fowler Biotechnology Co., Ltd.) for synchronization. Osteoblasts were randomly divided into the control and treatment groups. Groups were treated with $0,1,10,20,50$ or $100 \mathrm{ng} / \mathrm{ml}$ of IL-17F (R\&D Systems, Inc.) in low glucose (1 g/l) DMEM supplemented with $10 \%$ FBS (Jinan Fowler Biotechnology Co., Ltd.). MTT analysis. Osteoblasts $\left(4 \times 10^{4} /\right.$ well) in a 96 -well plate were incubated with $0,1,10,20,50$ or $100 \mathrm{ng} / \mathrm{ml} \mathrm{IL-17F}$ at $37^{\circ} \mathrm{C}$ for 1,3 or 5 days. Subsequently, $120 \mu \mathrm{l}$ MTT working fluid was added to each well at $37^{\circ} \mathrm{C}$ for $4 \mathrm{~h}$. DMSO was added to dissolve the purple formazan. The optical density (OD) of each well was measured at a wavelength of $570 \mathrm{~nm}$ using a microplate reader and was calculated as follows: $\mathrm{OD}=\left(\mathrm{OD}_{\text {treated }}-\mathrm{OD}_{\text {zero }}\right) /\left(\mathrm{OD}_{\text {control }}-\mathrm{OD}_{\text {zero }}\right)$.

ALP activity assay. Osteoblasts (4x10\%/well) in a 96-well plate were treated with $0,20,50$ or $100 \mathrm{ng} / \mathrm{ml} \mathrm{IL-17F}$ at $37^{\circ} \mathrm{C}$ for 1,3 or 5 days. Subsequently, the cell supernatant was centrifugated at $1,600 \mathrm{x}$ g for $10 \mathrm{~min}$ at $25^{\circ} \mathrm{C}$ and ALP activity was detected using an ALP activity assay kit (Nanjing Jiancheng Bioengineering Institute), according to the manufacturer's protocol. The OD at a wavelength of $520 \mathrm{~nm}$ was determined utilizing a microplate reader and ALP activity was calculated as follows: ALP activity $=\left(\mathrm{OD}_{\text {test }}-\mathrm{OD}_{\text {control }}\right) /\left(\mathrm{OD}_{\text {standard value }}-\mathrm{OD}_{\text {control }}\right)$ $\mathrm{x} 0.02 \mathrm{mg} / \mathrm{ml} \mathrm{x} 100 \mathrm{ml}$.

Alizarin red staining. Osteoblasts $\left(5 \times 10^{5} / \mathrm{ml}\right)$ were inoculated at $37^{\circ} \mathrm{C}$ for $24 \mathrm{~h}$ in culture dishes prior to treatment with 0 or $100 \mathrm{ng} / \mathrm{ml}$ IL-17F. The medium was changed every 3 days. After 10 days, mineralized nodules were detected. Osteoblasts were rinsed twice with cold PBS buffer, fixed with $95 \%$ ethanol at $25^{\circ} \mathrm{C}$ for $10 \mathrm{~min}$ and incubated with $0.1 \%$ Alizarin Red dye (Beyotime Biotechnology) at $37^{\circ} \mathrm{C}$ for $30 \mathrm{~min}$ at $\mathrm{pH}$ 4.3. Subsequently, stained cells were observed under light microscope and a magnification of $\times 100$. Untreated cells were used as controls.

Reverse transcription-quantitative PCR (RT-qPCR). Osteoblasts $\left(2 \times 10^{5} /\right.$ well $)$ in a 6 -well plate were treated with $0,1,10,20,50$ or $100 \mathrm{ng} / \mathrm{ml} \mathrm{IL}-17 \mathrm{~F}$ for 1,3 or 5 days at $37^{\circ} \mathrm{C}$. Osteoblast RNA was extracted using the TRIzol ${ }^{\circledR}$ Plus kit (Jinan Fowler Biotechnology Co., Ltd.), according to the manufacturer's protocol. Total RNA was reverse transcripted into cDNA using the cDNA Synthesis kit (Jinan Fowler Biotechnology Co., Ltd.) for $15 \mathrm{~min}$ at $37^{\circ} \mathrm{C}$ and $5 \mathrm{~min}$ at $98^{\circ} \mathrm{C}$. Following this, the transcription levels were determined using a RT-PCR with SYBR-Green PCR kit (Jinan Fowler Biotechnology Co., Ltd.) according to the manufacturer's protocol utilizing the LightCycler 2.0 Real-Time PCR system (Roche Molecular Systems, Inc.). The thermocycling conditions were as 
Table I. Primers used for reverse transcription-quantitative PCR.

\begin{tabular}{lll}
\hline Gene & & \multicolumn{2}{c}{ Sequence $\left(5^{\prime}-3^{\prime}\right)$} \\
\hline IL-17A & F: & TCATAAGCGGTGGCGGTTCTC \\
& R: & AGTCATCTTCATCTCCGTGTCCTC \\
IL-17C & F: & CCTAGTGTTGCCTCCACGAGAG \\
& R: & TCCCAGGTCATCATCATTCCACAG \\
BMP-2 & F: & GATGTCACCCCGGCTGTGATGCG \\
& R: & GGGATGTCCTTTACCGTCGTGGCC \\
Noggin & F: & TCGCCCTGGTGGTGGTCCTGG \\
& R: & GCAGCGAGCGCAGCAGCGTCT \\
Runx2 & F: & CATGGCCGGGAATGATGAG \\
& R: & TGTGAAGACCGTTATGGTCAAAGTG \\
Osterix & F: & GGATGGCGTCCTCTCTGCTT \\
& R: & TGTATGGCTTCTTTGTGCCCTCT \\
3-actin & F: & GTGGGCCGCTCTAGGCACCA \\
& R: & CGGTTGGCCTTAGGGTTCAGGGGG
\end{tabular}

IL, interleukin; BMP-2, bone morphogenetic protein-2; Runx2, Runt-related transcription factor-2; F, forward; R, reverse.

follows: $95^{\circ} \mathrm{C}$ for $30 \mathrm{sec}$; followed by 40 cycles of $95^{\circ} \mathrm{C}$ for $15 \mathrm{sec}, 60^{\circ} \mathrm{C}$ for $10 \mathrm{sec}$ and $72^{\circ} \mathrm{C}$ for $30 \mathrm{sec}$. The expression levels of the following genes were measured via qPCR: IL-17RA, IL-17RC, BMP-2, Noggin, Runx2 and Osterix. The sequences of the primers used for qPCR are listed in Table I. Arithmetic formulae $\left(2^{-\Delta \Delta C q}\right.$ method) was used to determine relative changes in gene expression over the internal control, $\beta$-actin (29).

Western blotting. Osteoblasts were treated with $0,1,10,20,50$ or $100 \mathrm{ng} / \mathrm{ml} \mathrm{IL-17F}$ for 3 days at $37^{\circ} \mathrm{C}$. Osteoblasts were rinsed with ice-cold PBS, collected, lysed with lysis buffer (Beyotime Institute of Biotechnology) and centrifuged at $16,000 \times \mathrm{g}$ for $15 \mathrm{~min}$ at $4^{\circ} \mathrm{C}$. Total protein was quantified using a BCA kit (Beyotime Institute of Biotechnology) according to the manufacturer's protocol. Protein $(20 \mu \mathrm{g})$ from each sample were then separated on $10 \%$ SDS-PAGE gel and transferred to a PVDF membrane. The membrane was blocked with 5\% BSA in Tris-buffered saline containing $0.1 \%$ Tween-20 for $90 \mathrm{~min}$ at $37^{\circ} \mathrm{C}$. Following blocking, the membranes were incubated with primary antibodies targeted against: IL-17RA (cat. no. ab180904; 1:1,000; Abcam), ERK1/2 (cat. no. ab17942; 1:1,000; Abcam), phosphorylated (p)-ERK1/2 (cat. no. ab17942; 1:1,000; Abcam), BMP-2 (cat. no. ab14933; 1:1,000; Abcam), Runx2(cat. no. ab23981; 1:500; Abcam), Osterix (cat. no. ab22552; 1:500; Abcam) and Noggin (cat. no. ab16054; 1:1,000; Abcam) overnight at $4^{\circ} \mathrm{C}$. Subsequently, the membranes were incubated with appropriate IRDye $800 \mathrm{CW}$-conjugated secondary antibodies (cat. no. ab253031; 1:4,000; Abcam) for $2 \mathrm{~h}$ at $37^{\circ} \mathrm{C}$. Protein bands were visualized using an ECL kit (Gibco; Thermo Fisher Scientific, Inc.), according to the manufacturer's protocol. Antibody-specific binding intensity was detected using an Odyssey luminescence apparatus (LI-COR Biosciences). The obtained bands were quantified using Quantity One software (version 25.0; Bio-Rad Laboratories, Inc.) and ratios of the protein of interest and $\beta$-actin were calculated to determine changes in protein levels.

Osteoblasts were cultured for 3 days at $37^{\circ} \mathrm{C}$ with the following treatments: i) No treatment; ii) $100 \mathrm{ng} / \mathrm{ml} \mathrm{IL-17F}$ treatment; or iii) $100 \mathrm{ng} / \mathrm{ml} \mathrm{IL}-17 \mathrm{~F}+10 \mu \mathrm{M}$ U0126 (Beyotime Institute of Biotechnology) treatment (specific MAPK/ERK1/2 inhibitor). Subsequently, phosphorylated (p)-ERK1/2, Runx2 and Osterix protein expression levels were assessed via western blotting, according to the aforementioned protocol.

Statistical analysis. Experiments were performed in triplicate. Statistical analyses were conducted using SPSS software (version 19.0; IBM Corp.). Data are presented as the mean \pm standard deviation. Comparisons among multiple groups were analyzed using two-way (Figs. 2, 3 and 4A-D) or one-way (Figs. 4F and 5) ANOVA followed by Tukey's (equal variance assumed) or Dunnett's T3 (equal variance not assumed) post hoc tests. $\mathrm{P}<0.05$ was considered to indicate a statistically significant difference.

\section{Results}

Calvarial osteoblast cell isolation, culture and identification. The characteristics and proliferation of the adherent cells was in accordance with the features of osteoblasts (Fig. 1). The ALP staining results demonstrated that the positive cells, which were osteoblasts, exhibited numerous black dye precipitates. ALP staining was not quantified. The ALP-positive rate of osteoblasts derived from the trypsin and type II collagenase method and the improved tissue-culture method was $>95 \%$.

IL-17F promotes osteoblast proliferation. To assess the direct effects of IL-17F on osteoblast proliferation, rat osteoblasts were treated with various concentrations of IL-17F $(1,10,20,50$ or $100 \mathrm{ng} / \mathrm{ml})$ for 1,3 or 5 days (Fig. 2A). The MTT assay results demonstrated that osteoblast proliferation was increased by 20,50 and $100 \mathrm{ng} / \mathrm{ml}$ IL-17F in a dose- and time-dependent manner compared with the control group. Furthermore, the maximal positive effect of IL-17F on cell proliferation was observed with a concentration of $100 \mathrm{ng} / \mathrm{ml}$ on day 5. By contrast, treatment with 1 and $10 \mathrm{ng} / \mathrm{ml} \mathrm{IL-17F}$ had no significant effect on osteoblast proliferation compared with the control group.

IL-17F promotes osteoblast ALP activity. ALP activity is a key marker in the early stage of osteoblast differentiation (30). To investigate whether IL-17F promoted osteoblast ALP activity, cells were treated with 20,50 or $100 \mathrm{ng} / \mathrm{ml}$ IL-17F for 1, 3 or 5 days (Fig. 2B). ALP activity was only significantly increased in the $100 \mathrm{ng} / \mathrm{ml}$ IL-17F group compared with the control group at each time point. However, treatment with 20 and $50 \mathrm{ng} / \mathrm{ml} \mathrm{IL-17F}$ had no significant effect on ALP activity compared with the control group.

$I L-17 F$ promotes osteoblast mineralization activity. The effects of IL-17F on mineralization activity were examined by measuring mineral nodule formation. The results demonstrated that the number of mineralized nodules was markedly increased following treatment with $100 \mathrm{ng} / \mathrm{ml} \mathrm{IL-17F}$ compared 

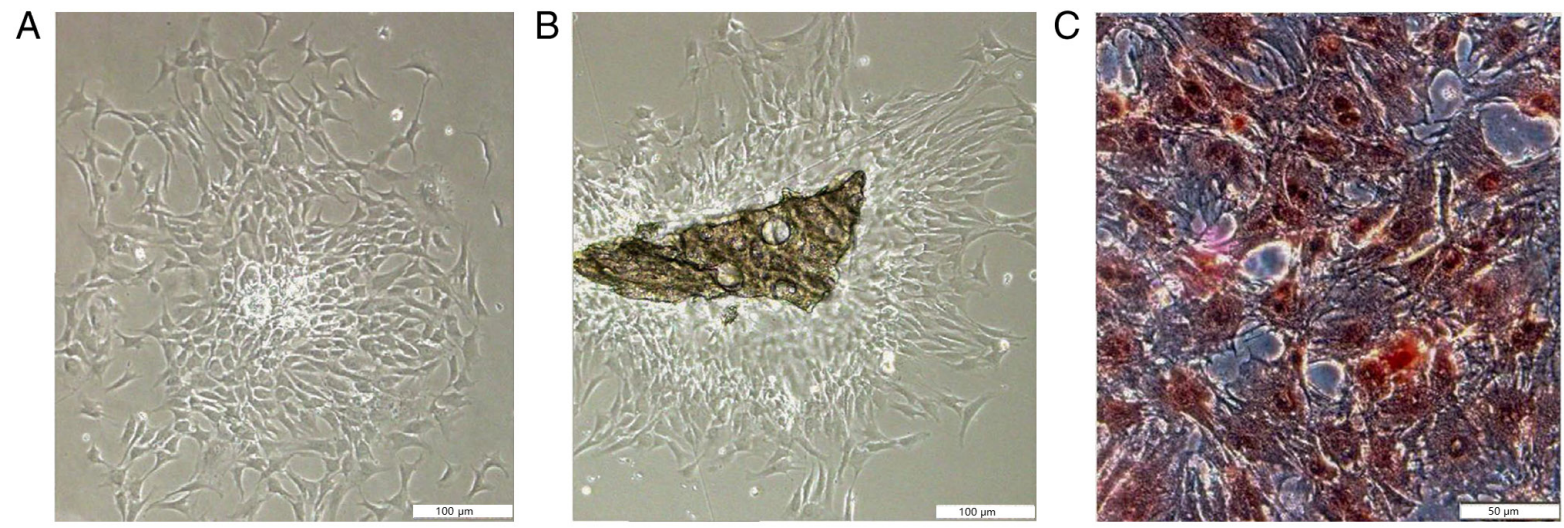

Figure 1. Calvaria-derived rat osteoblast culture and identification. (A) Primary osteoblasts were derived via the trypsin and type II collagenase method, and (B) the improved tissue-culture method. (C) Following alkaline phosphatase staining, black precipitations were observed in the cytoplasm and endonuclei of osteoblasts.

with the control group, as evidenced by orange patches/blocks (Fig. 2C and D).

IL-17F treatment increases IL-17RA and IL-17RC $m R N A$ expression levels. To determine whether IL-17F receptors participated in IL-17F-mediated promotion of osteogenesis, the mRNA expression levels of IL-17RA and IL-17RC were determined via RT-qPCR (Fig. 3). At each time point, IL-17RA mRNA expression levels were significantly increased in the 20,50 and $100 \mathrm{ng} / \mathrm{ml} \mathrm{IL-17F}$ groups compared with the control group. However, IL-17RC mRNA expression levels were only significantly increased in the $100 \mathrm{ng} / \mathrm{ml}$ IL-17F group compared with the control group. Therefore, the results suggested that IL-17RA was associated with the IL-17F-mediated promotion of osteogenesis with low concentrations of IL-17F (20 and $50 \mathrm{ng} / \mathrm{ml}$ ); however, at a high concentration $(100 \mathrm{ng} / \mathrm{ml})$, IL-17F interacted with both IL-17RA and IL-17RC.

IL-17F upregulates BMP-2/Runx2/Osterix mRNA expression and downregulates Noggin mRNA expression. The mRNA expression levels of BMP-2, Runx2, Osterix and Noggin were examined to determine the effects of IL-17F on osteoblasts. Because osteoblast proliferation and differentiation demonstrated no significant increase or decrease in 1 and $10 \mathrm{ng} / \mathrm{ml} \mathrm{IL}-17 \mathrm{~F}$ groups, Runx 2 and Osterix mRNA expression levels were not detected in these two groups. IL-17F (20, 50 and $100 \mathrm{ng} / \mathrm{ml})$ significantly increased BMP-2 mRNA expression levels on days 1,3 and 5 compared with the control group, particularly in the $100 \mathrm{ng} / \mathrm{ml} \mathrm{IL-17F}$ group (Fig. 4A). As an antagonist to BMP-2, Noggin mRNA expression levels displayed an opposite trend to BMP-2 in response to IL-17F treatment (Fig. 4D). The results indicated that compared with the control group, the mRNA expression levels of Runx2 and Osterix were significantly increased in a dose-dependent manner in the 20, 50 and $100 \mathrm{ng} / \mathrm{ml}$ IL-17F groups, with peak expression levels observed on day 3 (Fig. 4B and C).

IL-17F promotes BMP-2/Runx2/Osterix protein expression and downregulates Noggin protein expression. To further determine the effects of IL-17F on BMP-2, Runx2, Osterix and Noggin, western blotting analysis was conducted on day 3 to measure protein expression levels (Fig. 4E and F).
Following treatment with 50 or $100 \mathrm{ng} / \mathrm{ml} \mathrm{IL}-17 \mathrm{~F}$, the protein expression levels of BMP-2, Runx2 and Osterix were significantly increased, whereas Noggin expression levels were significantly decreased compared with the control group. IL-17F-induced alterations in protein expression were consistent with IL-17F-induced alterations in mRNA expression. By contrast, treatment with 1,10 or $20 \mathrm{ng} / \mathrm{ml} \mathrm{IL-17F} \mathrm{had}$ no significant effect on BMP-2, Runx2, Osterix and Noggin protein expression levels compared with the control group.

IL-17F-induced p-ERK1/2, Runx2 and Osterix protein expression is inhibited by U0126. To further verify whether p-ERK1/2 served a role in IL-17F-mediated osteoblastogenesis, a specific MAPK/ERK1/2 inhibitor (U0126) was used (Fig. 5). Following treatment with $100 \mathrm{ng} / \mathrm{ml} \mathrm{IL}-17 \mathrm{~F}$ for 3 days, p-ERK, p-ERK1/2, Runx 2 and Osterix expression levels were significantly increased compared with the control group. Co-treatment with U0126 significantly reversed IL-17F-induced protein expression. However, no significant differences were observed in the expression of p-ERK, Runx2 and Osterix between the control group and IL-17F+U0126 groups.

\section{Discussion}

The IL-17F cytokine was reported for the first time in 2001 and is expressed in Th17, natural killer, monocytes and T-cells $(31,32)$. IL-17F is involved in numerous inflammatory and autoimmune settings, such as rheumatoid arthritis, asthma, psoriasis, systemic lupus erythematosus and cancer (33-37). IL-17F has attracted increasing attention in bone disease research (38). The results of the present study suggested that IL-17F exerted a pro-osteogenic effect on calvaria-derived rat osteoblasts. Compared with the control group, osteoblast proliferation was significantly increased in a dose- and time-dependent manner following treatment with 20,50 or $100 \mathrm{ng} / \mathrm{ml}$ IL-17F. Treatment with $100 \mathrm{ng} / \mathrm{ml}$ IL-17F significantly promoted osteoblast ALP activity and mineralized nodule expression compared with the control group, which represented the capacity of differentiation and mineralization.

BMP-2 is one the most widely studied BMPs with the most potent bone inductive activity and has been reported 
A

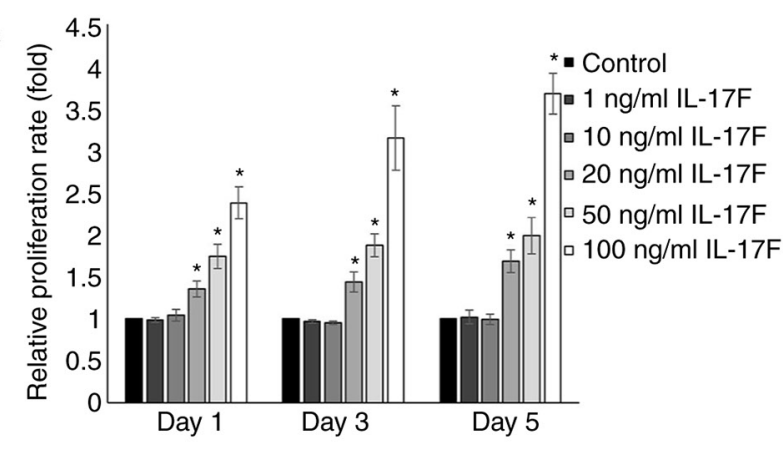

C

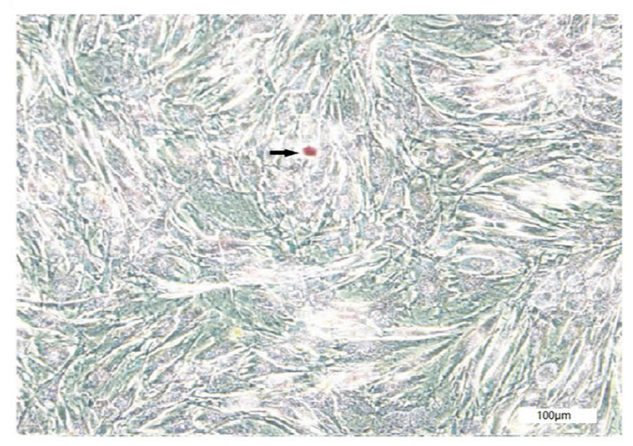

B

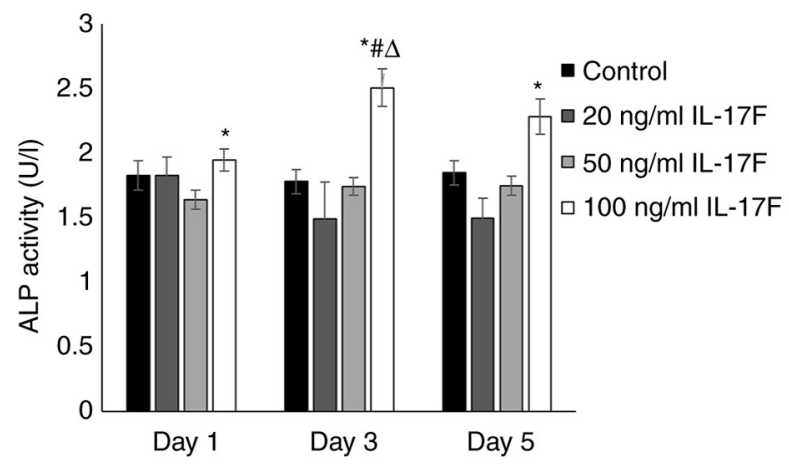

D

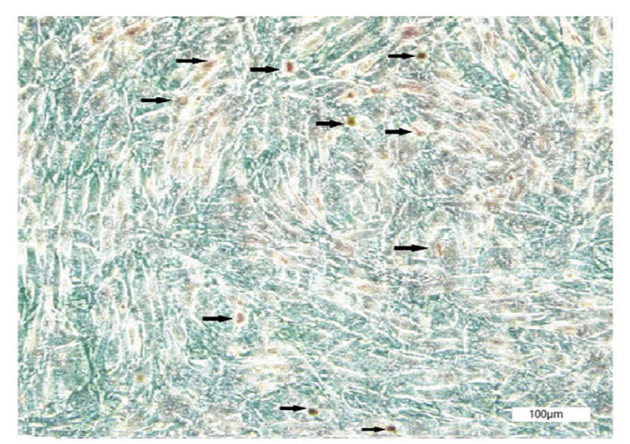

Figure 2. IL-17F promotes rat osteoblast proliferation, differentiation and mineralization activity. (A) IL-17F promotes osteoblast proliferation in a dose- and time-dependent manner. (B) IL-17F (100 ng/ml) promoted osteoblast ALP activity, reaching a maximal effect at day 3. (C) Few mineral nodules were observed in the control group, (D) whereas numerous mineral nodules were observed in the IL-17F (100 ng/ml) group. Mineralized nodules are indicated by black arrows. " $\mathrm{P}<0.05$ vs. control; ${ }^{*} \mathrm{P}<0.05$ vs. $20 \mathrm{ng} / \mathrm{ml}$ IL-17F; ${ }^{\Delta} \mathrm{P}<0.05$ vs. $50 \mathrm{ng} / \mathrm{ml}$ IL-17F. IL-17F, interleukin-17F; ALP, alkaline phosphatase.

A

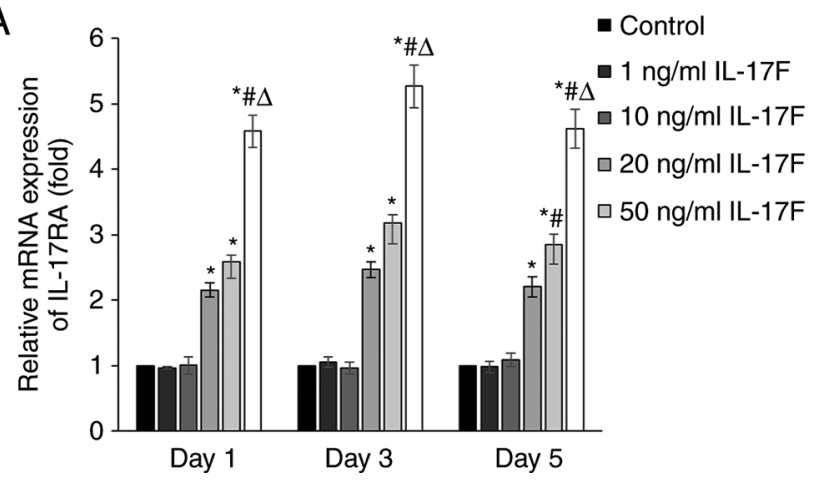

$\mathrm{B}$

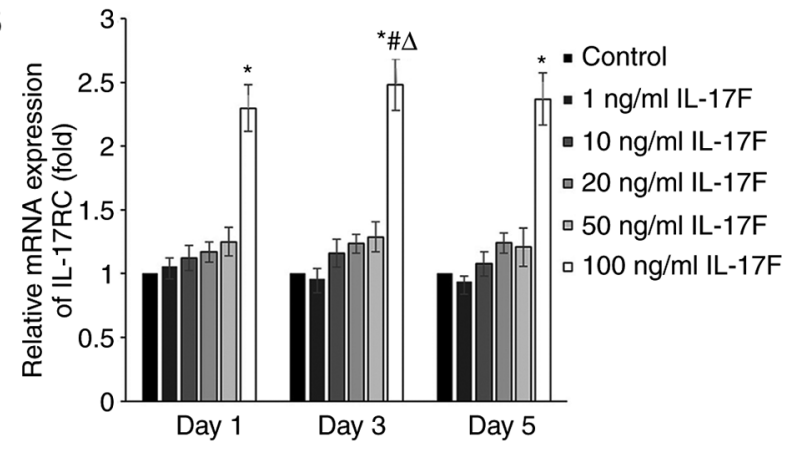

Figure 3. IL-17F increases IL-17RA and IL-17RC mRNA expression levels in rat osteoblasts. (A) IL-17RA and (B) IL-17RC expression levels in 20, 50 and $100 \mathrm{ng} / \mathrm{ml} \mathrm{IL-17F-treated} \mathrm{osteoblasts.}{ }^{*} \mathrm{P}<0.05$ vs. control; ${ }^{*} \mathrm{P}<0.05$ vs. $20 \mathrm{ng} / \mathrm{ml} \mathrm{IL-17F}$; ${ }^{4} \mathrm{P}<0.05$ vs. $50 \mathrm{ng} / \mathrm{ml} \mathrm{IL}-17 \mathrm{~F}$. IL-17F, interleukin-17F; IL-17R, interleukin-17 receptor.

to induce osteogenic differentiation in vitro $(39,40)$ and bone formation in vivo (41). The BMP-2 signaling pathway is a vital positive modulator of bone homeostasis $(42,43)$. BMP-2 binding to its receptors regulates target genes, such as Runx2 and Osterix (44). In the present study, compared with the control group, BMP-2, Runx2 and Osterix mRNA expression levels were increased by IL-17F treatment in rat osteoblasts, with expression levels peaking at a concentration of $100 \mathrm{ng} / \mathrm{ml}$ on day 3 , which was consistent with ALP activity. The promoting effect of IL-17F was also observed at the protein level. Therefore, the results indicated that promoting effects of IL-17F on osteoblasts occurred via stimulation of BMP-2, Runx2 and Osterix signaling pathway expression.
Noggin, an extracellular BMP antagonist, specifically blocks BMP/BMP receptor interaction, inhibits the phosphorylation of downstream targets and suppresses the activity of osteoblasts $(45,46)$. Yunan et al $(47)$ demonstrated that there may be a negative feedback regulation of Noggin in the BMP signaling pathway in vitro. In the present study, IL-17F treatment upregulated BMP-2 expression and downregulated Noggin expression in osteoblasts compared with the control group.

In the current study, IL-17RA and IL-17RC served differential roles relative to low and high concentrations of IL-17F. Following treatment with 20 or $50 \mathrm{ng} / \mathrm{ml}$ IL-17F, IL-17RA was increased compared with the control group. However, when osteoblasts were treated with $100 \mathrm{ng} / \mathrm{ml} \mathrm{IL}-17 \mathrm{~F}$, both 
A
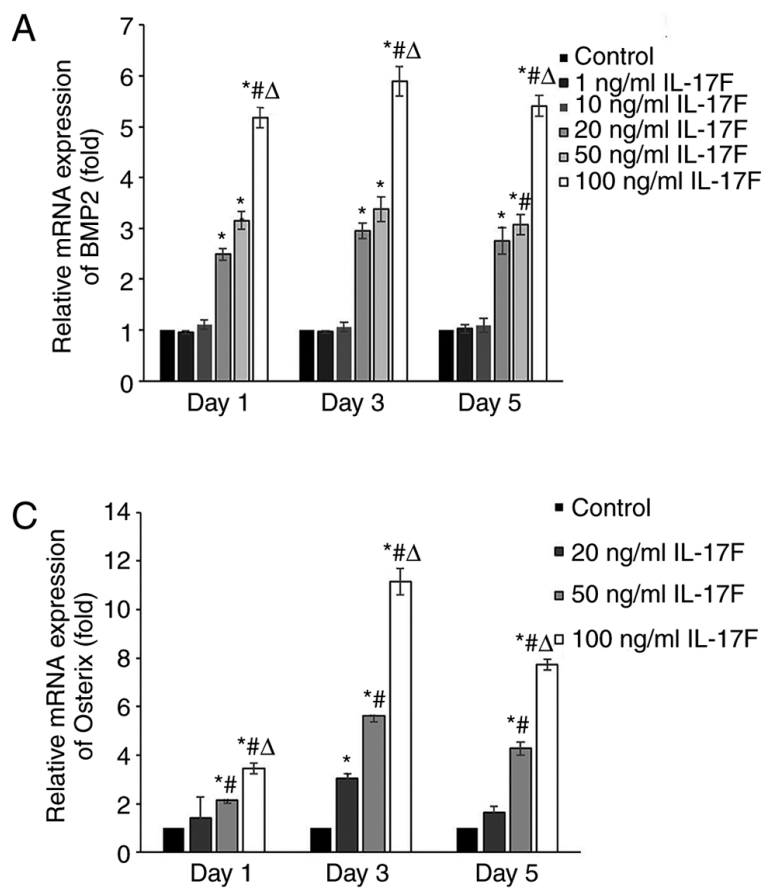

E

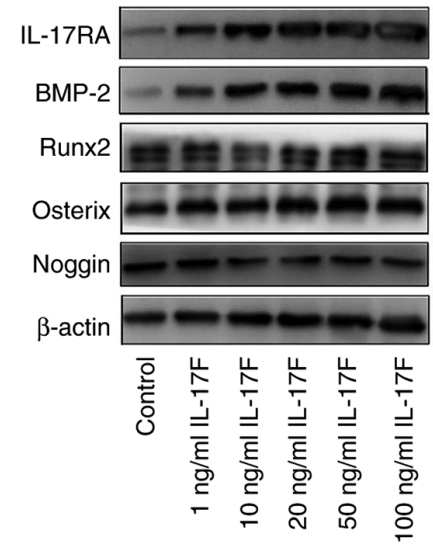

B
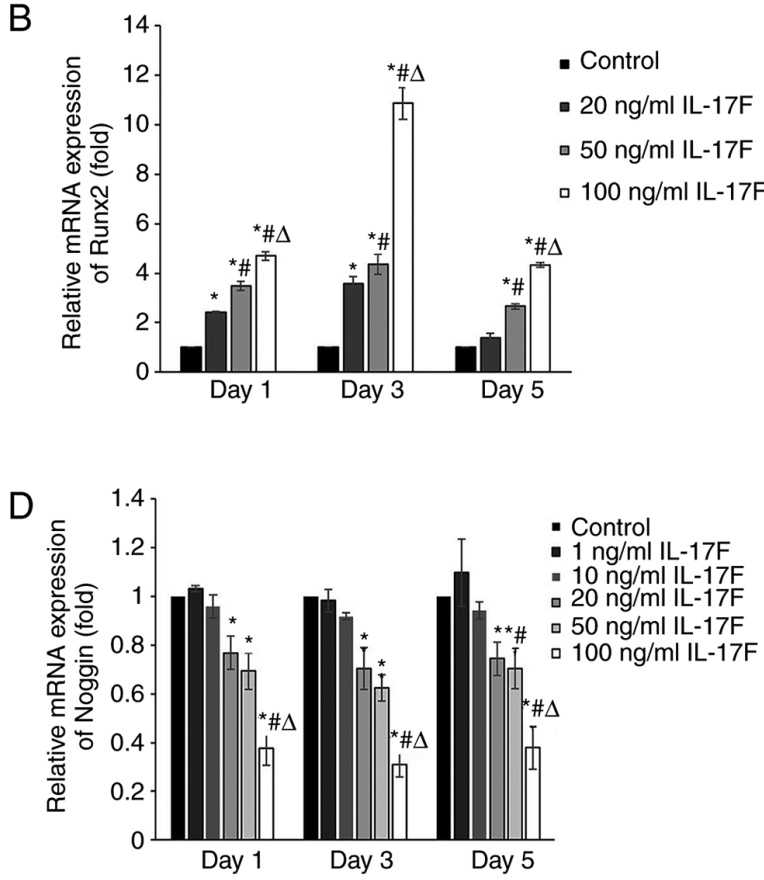

$\mathrm{F}$

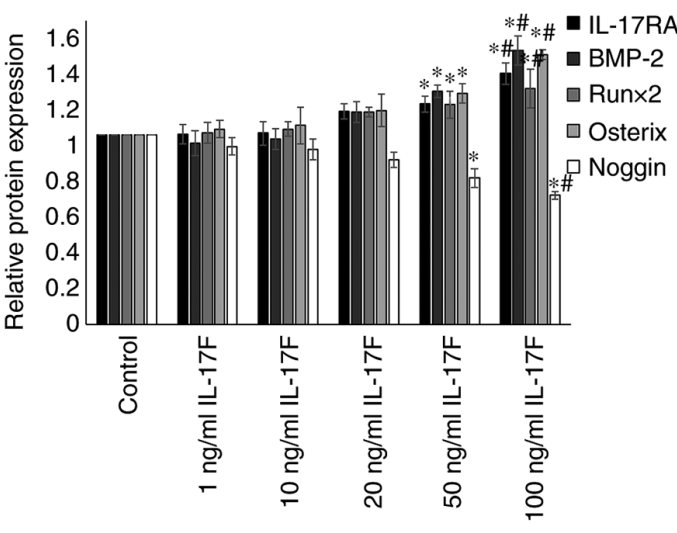

Figure 4. IL-17F upregulates BMP-2, Runx2 and Osterix expression levels and downregulates Noggin expression levels. (A) BMP-2, (B) Runx2, (C) Osterix and (D) Noggin mRNA expression levels in IL-17F-treated osteoblasts. Protein expression levels of IL-17RA, BMP-2, Runx2, Osterix and Noggin were determined by (E) western blotting and (F) semi-quantified. ${ }^{~} \mathrm{P}<0.05$ vs. control; ${ }^{*} \mathrm{P}<0.05$ vs. $20 \mathrm{ng} / \mathrm{ml} \mathrm{IL-17F;}{ }^{\Delta} \mathrm{P}<0.05$ vs. $50 \mathrm{ng} / \mathrm{ml} \mathrm{IL-17F}$. IL-17, interleukin-17; BMP-2, bone morphogenetic protein-2; Runx2, Runt-related transcription factor-2; IL-17R, interleukin-17 receptor.
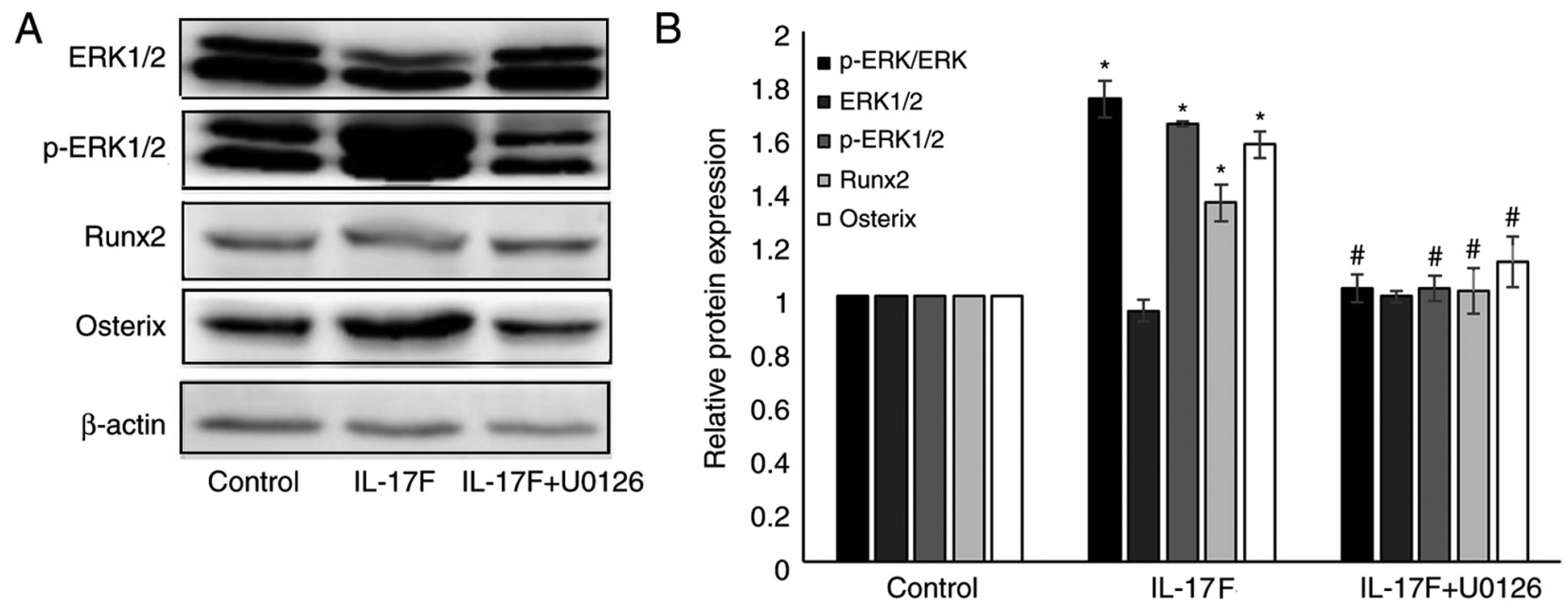

Figure 5. IL-17F increases p-ERK1/2, Runx2 and Osterix expression levels, but U0126 reverses IL-17F-induced expression. Protein expression levels were (A) determined by western blotting and (B) semi-quantified. ${ }^{\text {}} \mathrm{P}<0.05$ vs. control; ${ }^{~} \mathrm{P}<0.05$ vs. IL-17F. IL-17F, interleukin-17F; p, phosphorylated; Runx2, Runt-related transcription factor-2. 
IL-17RA and IL-17RC expression levels were increased compared with the control group. The peak mRNA expression levels of IL-17RA and IL-17RC mRNA were observed on day 3 following IL-17F treatment, which was not consistent with the proliferation assay results, but was in accordance with BMP-2/Runx2/Osterix mRNA expression and ALP activity. The expression of IL-17RC displayed a similar trend to ALP activity regarding time and dose. Therefore, the results suggested that IL-17F bound to different receptors at different time periods. The different requirements of IL-17RA and IL-17RC in combination with IL-17F observed in the present study corroborated the significance of precise ligand-receptor interaction in osteoblasts.

MAPK/ERK1/2 has been reported to regulate the cell proliferation, differentiation and apoptosis $(26,27)$. The significance of the MAPK/ERK1/2 signaling pathway in IL-17F was verified by performing western blotting. The expression levels of Runx2 and Osterix were higher in osteoblasts in $100 \mathrm{ng} / \mathrm{ml}$ IL-17F-treated osteoblasts on day 3 compared with the control group. When the MAPK/ERK1/2 inhibitor, U0126, was employed, IL-17F-induced upregulation of p-ERK1/2, Runx2 and Osterix was reversed. However, U0126 had no significant effect on Runx2 and Osterix expression compared with the control group. The results indicated that activation of the MAPK/ERK1/2 signaling pathway was essential for the effects of IL-17F on osteoblasts.

In conclusion, the results of the present study demonstrated that IL-17F promoted osteogenesis, including proliferation, differentiation and mineralization activity. The pro-osteogenic effects were associated with the upregulation of BMP-2/Runx2/Osterix expression and the downregulation of Noggin expression. The IL-17 receptors, IL-17RA and IL-17RC, were involved in the process. IL-17F promoted osteoblastic osteogenesis via the MAPK/ERK1/2-mediated signaling pathway. Therefore, IL-17F may serve as a therapeutic target for metabolic bone diseases.

\section{Acknowledgements}

Not applicable.

\section{Funding}

The present study was supported by the Natural Science Foundation of Shandong Province (grant no. ZR2014HM055).

\section{Availability of data and materials}

The datasets used and/or analyzed during the current study are available from the corresponding author on reasonable request.

\section{Authors' contributions}

LY and NZ majorly contributed to drafting the manuscript. LY designed the current study and interpreted results. NZ performed the rat osteoblast isolation, culture and identification. XL, XZ and LC performed RT-qPCR and western blotting. MC and YJ performed the proliferation, differentiation and mineralization ability detection assays, as well as part of the western blotting experiments. All authors read and approved the final manuscript.

\section{Ethics approval and consent to participate}

The present study was approved by the Medical Ethical Committee of Jinan Central Hospital, Jinan, China (approval no. GG2016-006-02).

\section{Patient consent for publication}

Not applicable.

\section{Competing interests}

The authors declare that they have no competing interests.

\section{References}

1. Weitzmann MN and Pacifici R: Estrogen deficiency and bone loss: An inflammatory tale. J Clin Invest 116: 1186-1194, 2006.

2. Harrington LE, Hatton RD, Mangan PR, Turner H, Murphy TL, Murphy KM and Weaver CT: Interleukin 17-producing CD4+ effector $\mathrm{T}$ cells develop via a lineage distinct from the $\mathrm{T}$ helper type 1 and 2 lineages. Nat Immunol 6: 1123-1132, 2005.

3. Chyuan IT and Chen JY: Role of interleukin-(IL-) 17 in the pathogenesis and targeted therapies in spondyloarthropathies. Mediators Inflamm 2018: 2403935, 2018.

4. Wu S, Meng Z and Zhang Y: Correlation between rheumatoid arthritis and immunological changes in a rheumatoid arthritis rat model. J Biol Regul Homeost Agents 32: 1461-1466, 2018.

5. Koo BS, Jo S, Kwon E, Shin JH, Hur JW and Kim TH: Effect of biologics in the level of cytokines in the synovial fluid of patients with ankylosing spondylitis. Korean J Intern Med 35: 465-473, 2020

6. Kim HJ, Seo SJ, Kim JY, Kim JY, Kim YG and Lee Y: IL-17 promotes osteoblast differentiation, bone regeneration, and remodeling in mice. Biochem Biophys Res Commun 524: 1044-1050, 2020.

7. Miossec P and Kolls JK: Targeting IL-17 and TH17 cells in chronic inflammation. Nat Rev Drug Discov 11: 763-776, 2012.

8. Patel DD and Kuchroo VK: Th17 cell pathway in human immunity: Lessons from genetics and therapeutic interventions. Immunity 43: 1040-1051, 2015.

9. Ono T, Okamoto K, Nakashima T, Nitta T, Hori S, Iwakura Y and Takayanaqi H: IL-17 produing $\gamma \delta$ T cells enhance bone regeneration. Nat Commun 7: 10928, 2016.

10. Osta B, Lavocat F, Eljaafari A and Miossec P: Effects of interleukin-17A on osteogenic differentiation of isolated human mesenchymal stem cells. Front Immunol 5: 425, 2014.

11. Nam D, Mau E, Wang Y, Wright D, Silkstone D, Whetstone H, Whyne C and Alman B: T-Lymphocytes enable osteoblast maturation via IL-17F during the early phase of fracture repair. PLoS One 7: e40044, 2012.

12. Wang Y, Kim J, Chan A, Whyne C and Nam D: A two phase regulation of bone regeneration: IL-17F mediates osteoblastogenesis via C/EBP- $\beta$ in vitro. Bone 116: 47-57, 2018.

13. Vachhani K, Pagotto A, Wang Y, Whyne C and Nam D: Design of experiments confirms optimization of lithium administration parameters for enhanced fracture healing. J Biomech 66: 153-158, 2018.

14. Yang W, Guo D, Harris MA, Cui Y, Gluhak-Heinrich J, Wu J, Chen XD, Skinner C, Nyman JS, Edwards JR, et al: Bmp2 in osteoblasts of periosteum and trabecular bone links bone formation to vascularization and mesenchymal stem cells. J Cell Sci 126: 4085-4098, 2013.

15. Salazar VS, Gamer LW and Rosen V: BMP signaling in skeletal development, disease and repair. Nat Rev Endocrinol 12: 203-221, 2016.

16. Cohen MM: Bone morphogenetic proteins with some comments on fibrodysplasia ossificans progressive and NOGGIN. Am J Med Genet 109: 87-92, 2002.

17. Canalis E, Economides AN and Gazzerro E: Bone morphogenetic proteins, their antagonists, and the skeleton. Endocrine Rev 24: 218-235, 2003. 
18. Moffett SP, Dillon KA, Yerges LM, Goodrich LJ, Nestlerode C, Bunker CH, Wheeler VW, Patrick AL and Zmuda JM: Identification and association analysis of single nucleotide polymorphisms in the human noggin (NOG) gene and osteoporosis phenotypes. Bone 44: 999-1002, 2009.

19. Komori T: Regulation of osteoblast differentiation by transcription factors. J Cell Biochem 99: 1233-1239, 2006.

20. Amatya N, Garg AV and Gaffen SL: IL-17 signaling: The Yin and the Yang. Trends Immunol 38: 310-322, 2017.

21. Ely LK, Fischer S and Garcia KC: Structural basis of receptor sharing by interleukin 17 cytokines. Nat Immunol 10: 1245-1251, 2009.

22. Toy D, Kugler D, Wolfson M, Vanden Bos T, Gurgel J, Derry J, Tocker J and Peschon J: Cutting edge: Interleukin 17 signals through a heteromeric receptor complex. J Immunol 177: 36-39, 2006.

23. Gu C, Wu L and Li X: IL-17 family: Cytokines, receptors and signaling. Cytokine 64: 477-485, 2013.

24. Schwandner R, Yamaguchi K and Cao Z: Requirement of tumor necrosis factor receptor-associated factor (TRAF) 6 in interleukin 17 signal transduction. J Exp Med 191: 1233-1240, 2000.

25. Nguyen TT, Lian S, Ung TT, Xia Y, Han JY and Jung YD Lithocholic acid stimulates IL-8 expression in human colorectal cancer cells via activation of Erk1/2 MAPK and Suppression of STAT3 Activity. J Cell Biochem 118: 2958-2967, 2017.

26. Chen T, Huang H, Zhou Y, Geng L, Shen T, Yin S, Zhou L and Zheng S: HJURP promotes hepatocellular carcinoma proliferation by destabilizing p21 via the MAPK/ERK1/2 and AKT/GSK3 $\beta$ signaling pathways. J Exp Clin Cancer Res 37: 193, 2018.

27. Chen Q, Xia T and Ye ZW: New SD Rat osteoblasts by modified explant culture in vitro and identification. Acta Universitatis Medicinalis Anhui 47: 1124-1127, 2006.

28. Sun L and Hou JM: Primary culture and identification of rats cranial cover osteocytes. Med Innovation China 8: 17-19, 2011.

29. Livak KJ and Schmittgen TD: Analysis of relative gene expression data using real-time quantitative PCR and the 2(-Delta Delta C(T)) method. Methods 25: 402-408, 2001.

30. Orimo H: The mechanism of mineralization and the role of alkaline phosphatase in health and disease. J Nippon Med Sch 77: 4-12, 2010.

31. Starnes T, Robertson MJ, Sledge G, Kelich S, Nakshatri H, Broxmeyer HE and Hromas R: Cutting edge: IL-17F, a nove cytokine selectively express in activated $\mathrm{T}$ cells and monocytes, regulates angiogenesis and endothelial cell cytokine production. J Immunol 167: 4137-4140, 2001.

32. Kimura A and Kishimoto T: IL-6: Regulator of Treg/Th17 balance. Eur J Immunol 40: 1830-1835, 2010

33. Paradowska-Gorycka A, Sowinska A, Stypinska B, Grobelna MK, Walczyk M, Olesinska M, Piotrowski P and Jagodzinski PP: Impact of the IL-17F, IL-23 and IL-23R on susceptibility and phenotype of systemic lupus erythematosus. Autoimmunity 49 : 373-382, 2016

34. Soderstrom C, Berstein G, Zhang W, Valdez H, Fitz L, Kuhn M and Fraser S: Ultra-sensitive measurement of IL-17A and IL-17F in psoriasis patient serum and skin. AAPS J 19: 1218-1222, 2017.
35. Hatta M, Surachmanto EE, Islam AA and Wahid S: Expression of mRNA IL-17F and sIL-17F in atopic asthma patients. BMC Res Notes 10: 202, 2017.

36. Gomes da Silva IIF, Angelo HD, Rushansky E, Mariano MH, Diniz Maia MM and Eleuterio de Souza PRE: Interleukin (IL)-23 Receptor, IL-17A and IL-17F gene polymorphisms in brazilian patients with rheumatoid arthritis. Arch Immunol Ther Exp (Warsz) 65: 537-543, 2017.

37. Wang H, Zhang Y, Liu Z, Zhang Y, Zhao H and Du S: The IL-17A G-197A and IL-17F 7488T/C polymorphisms are associated with increased risk of cancer in Asians: A meta-analysis. Drug Des Devel Ther 9: 5159-5168, 2015.

38. Erkolİnal E, Görükmez O, Eroğlu S, Özemri SS, Solak Ö, Görükmez Ö and Yakut T: Associations between polymorphisms of IL-17F and IL-17A genes with disease activity and clinical outcome of Ankylosing Spondylitis. Acta Reumatol Port 41: 232-239, 2016.

39. Luu HH, Song WX, Luo X, Manning D, Lou J, Deng ZL, Sharff KA, Montag AG, Haydon RC and He TC: Distinct roles of bone morphogenetic proteins in osteogenic differentiation of mesenchymal stem cells. J Orthop Res 2: 665-677, 2007.

40. Taşli PN, Aydin S, Yalvaç ME and Sahin F: Bmp 2 and bmp 7 induce odonto- and osteogenesis of human tooth germ stem cells. Appl Biochem Biotechnol 172: 3016-3025, 2014.

41. Jimi E, Hirata S, Shin M, Yamazaki Mand Fukushima H: Molecular mechanisms of BMP-induced bone formation: Cross-talk between $\mathrm{BMP}$ and NF- $\mathrm{B}$ signaling pathways in osteoblastogenesis. Jpn Dent Sci Rev 46: 33-42, 2010.

42. Moon SH, Kim I and Kim SH: Mollugin enhances the osteogenic action of BMP-2 via the p38-Smad signaling pathway. Arch Pharm Res 40: 1328-1335, 2017.

43. Kim EC, Yoon SJ, Noh K and Lee DW: Dual effect of curcumin/BMP-2 loaded in HA/PLL hydrogels on osteogenesis in vitro and in vivo. J Nanosci Nanotechnol 17: 143-152, 2017.

44. Sun WL, Wang N and Xu Y: Impact of miR-302b on calcium-phosphorus metabolism and vascular calcification of rats with chronic renal failure by regulating BMP-2/Runx2/Osterix signaling pathway. Arch Med Res 49: 164-171, 2018.

45. Yu X, Kawakami H, Tahara N, Olmer M, Hayashi S, Akiyama R, Bagchi A, Lotz M and Kawakami Y: Expression of Noggin and Gremlin1 and its implications in fine tuning BMP activities in mouse cartilage tissues. J Orthop Res 35: 1671-1682, 2017.

46. AlShaibi HF, Ahmed F, Buckle C, Fowles ACM, Awlia J, Cecchini MG and Eaton C: The BMP antagonist Noggin is produced by osteoblasts in response to the presence of prostate cancer cells. Biotechnol Appl Biochem 65: 407-418, 2018.

47. Yunan MA, Ying Y, Huanhuan S, Zhaozeng S, Lin Z and Yunzhi FA: Effect of Noggin silencing on the BMP and Wnt signaling pathways. Acta Laboratorium Animalis Scientia Sinica 24: 475-480, 2016

This work is licensed under a Creative Commons Attribution-NonCommercial-NoDerivatives 4.0 International (CC BY-NC-ND 4.0) License. 